\title{
Building Users' Appraisal of Effective Fire Safety Management for Building Facilities in Malaysian Higher Education Institutions: A Pilot Study
}

\author{
Ibrahim Yakubu Ebenehi ${ }^{1,2}$, Sulzakimin Mohamed ${ }^{1}$, Norliana Sarpin ${ }^{1}$, Seow Ta Wee ${ }^{1}$, \\ Adejoh Ahmodu Adaji ${ }^{1,3}$
}

${ }^{1}$ Universiti Tun Hussein Onn Malaysia

101 Beg Berkunci, Parit Raja, Batu Pahat, Johor, 86400, Malaysia

${ }^{2}$ The Federal Polytechnic Bauchi

P. M. B. 0231 Bauchi, Bauchi State, Nigeria

${ }^{3}$ Kogi State Polytechnic Lokoja

P. M. B. 101 Lokoja, Kogi State, Nigeria

DOI: $10.22178 /$ pos. $41-2$

LCC Subject Category:

TH9025-9745

Received 14.11.2018

Accepted 10.12.2018

Published online 28.12.2018

Corresponding Author:

Ibrahim Yakubu Ebenehi

iyebenehi@gmail.com

(c) 2018 The Authors. This

article is licensed under a

Creative Commons

Attribution 4.0 License

(c) (i)

\begin{abstract}
Enormous investments had been made in Malaysian education sector of the economy especially in the higher education towards fulfilling a target of creating an attractive environment, conducive to learning and academic excellence. Building facilities account for a significant portion of investments in the sector. Since no building has immunity against fire, it has become imperative to research ways of ensuring the safety of built facilities and users from fire disaster. This research proposed a framework for effective fire safety management for buildings in Malaysian Higher Education Institutions. The report aims to display the results of the pilot study conducted among staff and students from selected universities in Johor Malaysia before carrying out the core survey to collect information from respondents. The pilot study sought to minimise errors in the questionnaire, makes the survey runs smoothly, facilitate the response rate, and provide a useful and valuable inquiry. The results include the descriptive statistics, reliability test, content and construct validity, and the normality test. The summary of the reliability test for each construct of the users' questionnaire, are Management, 0.910 ; fire safety equipment/system, 0.907 ; building components safety design, 0.917 . Furthermore, users' awareness and knowledge of fire safety, 0.948; users' attitude on fire safety, 0.885 and the effectiveness of fire safety management have a value 0.913 for Cronbach's Alpha Coefficient. The aggregate Descriptive Statistics results for Users/0ccupants Questionnaire show mean values between the ranges of 3.34 to 3.76 . The questionnaire had low dispersion and standard deviation values of less than 1 . The values of skewness and kurtosis were all within the recommended threshold of $-/+2$, an indication that all the constructs of the study were normally distributed. The results are a favourable indicator for proceeding with the core survey using the instrument.
\end{abstract}

Keywords: buildings; Malaysia; pilot study; effective fire safety management; higher education institutions.

\section{INTRODUCTION}

Fire Safety Management (FSM) refers to the implementation of policy, standards, tools, information, and practices in an organisation directed towards analysis, evaluation and control, of fire safety [15]. It is a continuous process of maintaining fire safety to reduce the number of fire incidents, the risk to lives and property to a low and acceptable level $[4,13,23]$. According to the Society of Fire Protection Engineers [25], Fire
Safety Management is a process of deciding the type of activities needed when fire hazards are identified, populations are exposed, and foreseeable risks predicted. Fire Safety Management aimed to educate building occupants to be proactive, responsible and responsive towards fire safety [1].

Fire Safety Management roles are critical in the prevention and control of fires, the building occupants' evacuation, as well as the maintenance 
of safety systems. According to [28], several factors influence the fire safety of an enterprise. Prominent among the elements is a human factor which deals with the level of personal awareness resulting from regular training to reduce the consequences of fire incidence. Also, fire safety management issues such as clear fire safety responsibility, perfect firefighting facilities could limit possible destruction to life and property. Then other factors that could affect fire safety include the condition of fire control facilities and some technical obstacle to fire protection such as evacuation difficulties, flammable material, toxic leaks, and the problem of water supply. Research conducted by [2], revealed a few factors that affect the effective management of fire safety in student housing. Those challenges include problems with electrical wiring and installations; inadequate water distribution system; inadequacies in the fire department; passive attitude of owners/management towards housekeeping and maintenance; passive attitude towards personal fire protection; high cost of installing fire protection system; little or no consideration for fireresistive building design and construction; poorly enforced and ineffective fire-related policies and regulations.

Furthermore, authors [21] itemised 16 ways of improving fire protection level of a building which includes compartmentation, fire resistance of structural elements, control of fire loads, maintenance of fire safety system, etc. Their listed items encompass those proposed by [18] and [14] which include prevention, detection, and suppression for ensuring a high level of fire safety in student housing facilities.

Additionally, as part of management procedures, the involvement of an independent auditor is necessary to regularly carry out fire protection audit at least two times a year [6]. Fire Safety Management Audit according to the British Safety Council [5] is a process which entails examining in detail the Fire Safety Management System (FSMS) and associated arrangements of an organisation. It focuses on the critical aspects of managing fire safety in the organisation and provide an organised path for constant change towards best practices. Figure 1 depicts the Audit Model for Fire Safety Management.

The audit model reflects the well-known management cycle called PLAN-DO-CHECK-ACT. The model evaluates both the preventive and protective Fire Safety Management System and ar- rangements against the current best practice techniques independently [5].

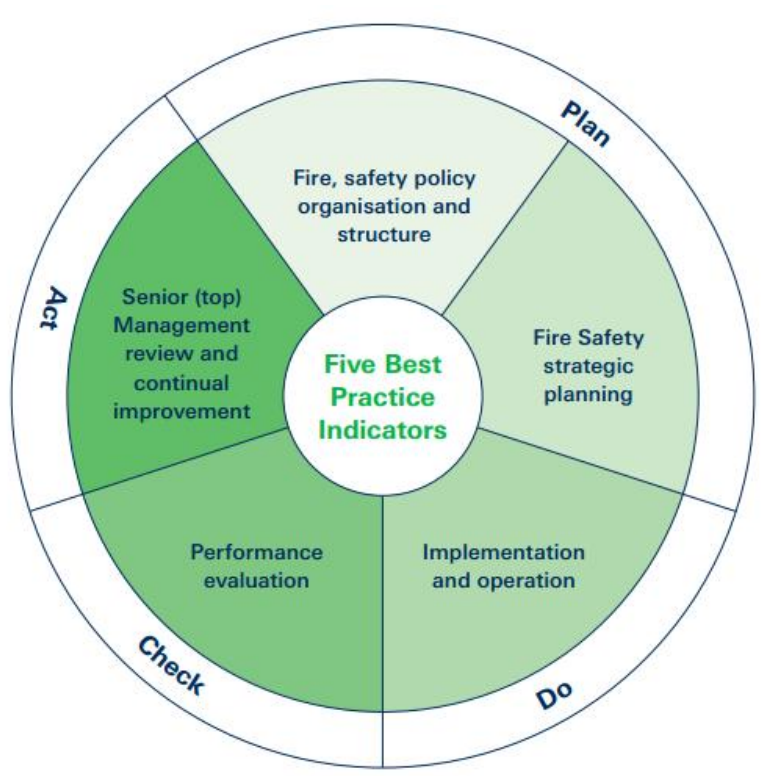

Figure 1 - Fire Safety Management Audit Model [5]

Building facilities in the Higher Education Institutions are of many categories and used for different purposes such as academics, administration, health services, residential and recreational activities. Student housing is among the Higher Education Institutions structures considered a high-risk facility where fires may likely get out of control without adequate and appropriate control and suppression systems [24]. Student housing facilities are dormitories which contain more than two sleeping or dwelling units, where the occupants are primarily permanent [17].

The need for considering a few sustainability issues and driver that could impact a new development as suggested by [12] include:

1. To increase the use of recycled materials for construction

2. To reduce waste on construction sites by encouraging the development of innovative construction methods such as modular construction

3. To increase the thickness of insulation towards meeting energy requirements

4. To improve the buildings airtightness

5. Identify buildings historically based on a traditional structure that need to be revisited for new materials

6. Understand the performance of new laminated glazing products. 
Although it is encouraging to embrace sustainability ideal while designing and constructing buildings, extra caution must be exercised to avoid compromising fire protection of buildings.

In the opinion of [16], an adequately managed building reduced the chances of fire outbreak and increased the possibility of successful occupants' evacuation in the event of an emergency. This research aims to develop an effective fire safety management framework for building facilities in Malaysian Higher Education Institutions. Sequel to the pilot study we proposed a conceptual framework for fire safety management for buildings in Malaysian universities based on design and management aspect of Higher Education Institutions buildings [9].
While the design involves the building characteristic and fire safety systems, the management aspect comprises operation/ maintenance and management approaches. The conceptual framework combines the fire prevention, fire control and post-fire egress' objectives of Fire Safety Management. Also, the level of users' awareness was conceptualised to influence their attitude towards fire safety. The integration of both the users of the building and management in the proposed framework is expected to ensure fire prevention through that the collective efforts of all and sundry. Figure 2 shows the proposed conceptual for Effective Fire Safety Management in Higher Education Institutions in Malaysia.

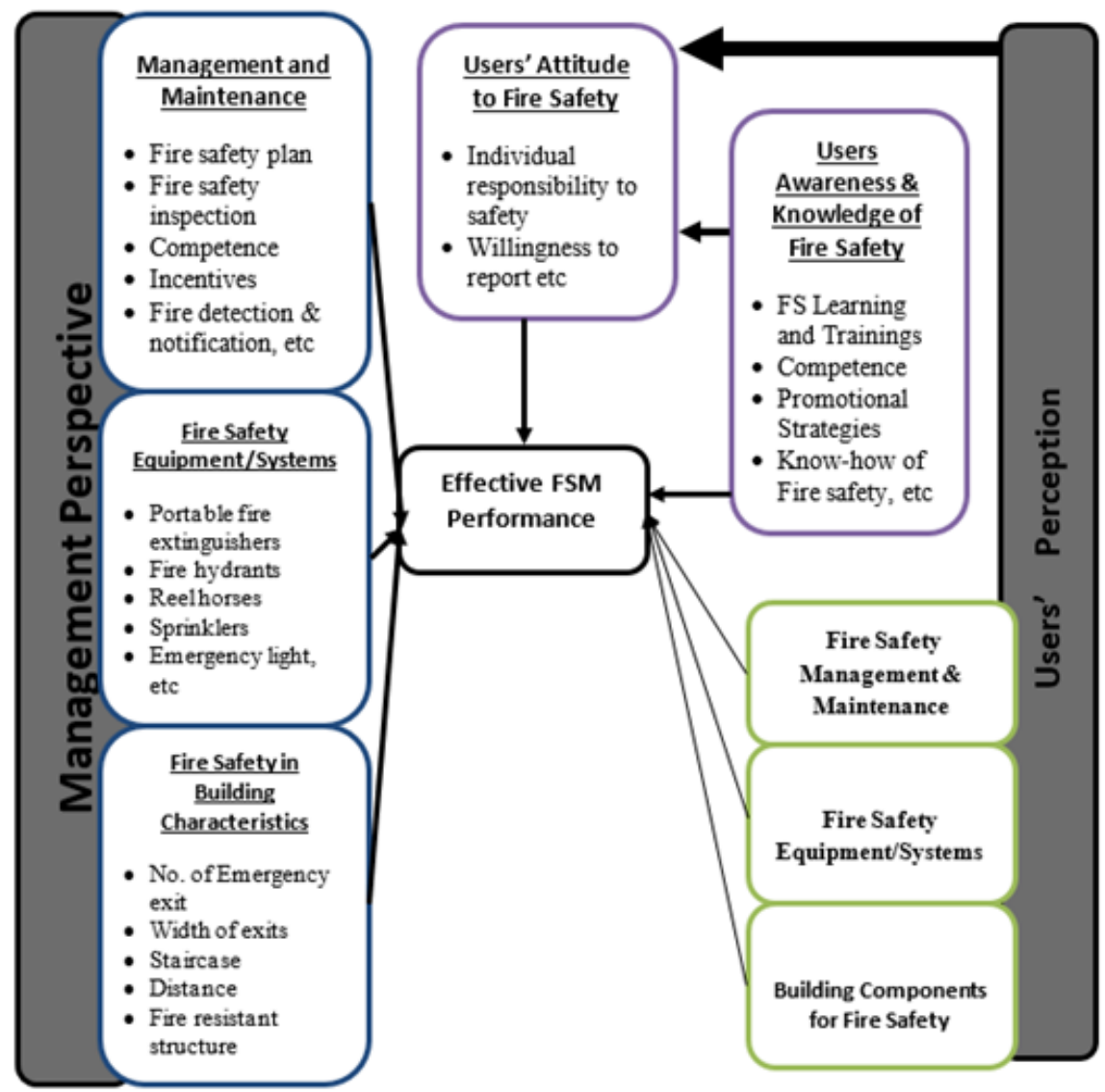

Figure 2 - The Effective Fire Safety Management Conceptual Framework [9]

\section{METHODOLOGY}

Pilot testing of questionnaire survey is a vital aspect in research design because; it helps to get the wordings of the questionnaire correctly and to increase the reliability, validity, and practicability of the survey [7]. It involves primarily the administration of the questionnaire to several respondents who are a representative of the target research sample and the subsequent use of statistical analysis and feedback to reduce the number of items in the questionnaire into a manageable number. Authors [7] highlighted that the pilot data obtained from the pilot test is analysed to determine the following: Reliability; Collinearity; Multiple regression; Factor analysis.

Before conducting the main survey to collect information from respondents to achieve the stated objectives, a pilot study was conducted. 
The pilot study aimed to ensure the reliability and validity of the developed research instrument to minimise errors in the questionnaire, makes the survey runs smoothly, facilitate response rate, and provide a useful and valuable questionnaire $[10,19,20]$ pointed that pilottesting of questionnaire ensures the inclusion of all relevant issues; the correctness of its order; identification of ambiguous or misleading statements, and make sure there is no omission of any critical matter from the questionnaire.

The instrument was pilot tested on sub-sample of the study sample. The collected data from the pilot study was analysed using the descriptive of the variables. The reliability was assessed using Cronbach's Alpha coefficient based on the recommendation of [22]. The skewness and kurtosis were used to evaluate the normality of the data based on the submission of [11] that the values of skewness and kurtosis should be within the range of $-/+2$ for the response to be considered normally distributed. Similarly, the missing values and outliers were observed and treated accordingly. The structure of the data was also assessed using factor analysis. The possibility of multicollinearity was examined using the Variance Inflation Factor (VIF) and Tolerance level which is required to be less than 10 and 1 respectively [22].

This report is based on questionnaires for User/Occupants of the Higher Education Institutions buildings administered to the respondents of selected universities within Johor, Malaysia.

\section{Pilot Instrument Administrations}

Table 1 shows the distribution of questionnaires, the numbers returned and considered valid for analysis.

Table 1 - Pilot Instrument administration

\begin{tabular}{|l|c|c|}
\hline \multirow{2}{*}{ Number of: } & \multicolumn{2}{|c|}{ Users / Occupants } \\
\cline { 2 - 3 } & Frequency & $\%$ \\
\hline $\begin{array}{l}\text { Questionnaires } \\
\text { Administered }\end{array}$ & 100 & 100 \\
\hline Returned & 81 & 81 \\
\hline Valid and Usable & 77 & 77 \\
\hline
\end{tabular}

Table 1 shows the number of questionnaires distributed to the respondents. We dispensed a total of 100 questionnaires to users/occupants of
Higher Education Institutions in Malaysian Higher Education Institutions of which $81 \%$ were returned. However, of the returned questionnaire 4 were discarded due to issues of outliers and missing entries leaving $77 \%$ valid response for the analysis, which shows good response rate.

\section{Data Descriptive, Normality, Reliability and Factorability}

These subsections provide the result of the pilot study descriptive, normality, reliability and factorability according to the constructs in the Users/Occupants' questionnaire. These constructs are Management, fire safety equipment/system, building components safety design, users' awareness and knowledge of fire safety, users' attitude on fire safety, and the effectiveness of fire safety management.

Table 2 shows the pilot result for the management construct which produces mean values ranging from 3.26 to 3.73 . The amount of skewness and kurtosis were all within the threshold of $-/+2$ [11]. All the variables under the construct have strong factor loadings which cumulatively explained $42.97 \%$ of the variance which is satisfactory. The reliability of the construct was assessed using Cronbach's Alpha coefficient which produced a value of 0.910 above the recommended minimum threshold of $0.7[11,22,26$, 27].

The outcome is an indication that the result obtained is adequate; the data is normally distributed and reliable. Hence, the instrument is considered valid for the leading survey of the research.

Table 3 shows the pilot result for the fire safety equipment/system construct produces mean values ranging from 3.19 to 3.82 . The values of skewness and kurtosis were all the threshold of /+2 [11]. All the variables under the construct have strong factor loadings which cumulatively explained $51.89 \%$ of the variance that is considered satisfactory except for Fire Safety Equipment/System 12 which has a value below the recommended level of 0.04 [22]. The reliability of the construct was assessed using Cronbach's Alpha coefficient which produced a value of 0.907 above the prescribed minimum threshold of 0.7 $[11,22,26,27]$. 
Table 2 - Pilot Result for Management

\begin{tabular}{|l|c|c|c|c|c|c|}
\hline \multirow{2}{*}{ Code } & \multirow{2}{*}{ Mean } & \multicolumn{2}{c|}{ Normality } & \multirow{2}{*}{$\begin{array}{c}\text { Factor } \\
\text { Loadings }\end{array}$} & $\begin{array}{c}\text { Variance } \\
\text { Explained }\end{array}$ & $\begin{array}{c}\text { Cronbach's } \\
\text { Alpha }\end{array}$ \\
\cline { 3 - 5 } Management 1 & 3.47 & -.379 & .072 & .668 & 42.97 & 0.910 \\
\hline Management 2 & 3.68 & -1.063 & 2.00 & .680 & & \\
\hline Management 3 & 3.44 & -.627 & .413 & .695 & & \\
\hline Management 4 & 3.53 & -.628 & .828 & .681 & & \\
\hline Management 5 & 3.45 & -.835 & .413 & .596 & & \\
\hline Management 6 & 3.45 & -.755 & .602 & .595 & & \\
\hline Management 7 & 3.55 & -.494 & .222 & .709 & & \\
\hline Management 8 & 3.58 & -.978 & .385 & .642 & & \\
\hline Management 9 & 3.55 & -.534 & -.076 & .779 & & \\
\hline Management 10 & 3.39 & -.342 & -.052 & .581 & & \\
\hline Management 11 & 3.60 & -.530 & .444 & .638 & & \\
\hline Management 12 & 3.60 & -.306 & .034 & .641 & & \\
\hline Management 13 & 3.62 & -.477 & .484 & .599 & & \\
\hline Management 14 & 3.73 & -.544 & .478 & .563 & & \\
\hline Management 15 & 3.61 & -.529 & .283 & .694 & & \\
\hline Management 16 & 3.26 & -.631 & .240 & .692 & & \\
\hline
\end{tabular}

Table 3 - Pilot Study Result for Fire Safety Equipment/System

\begin{tabular}{|c|c|c|c|c|c|c|}
\hline \multirow{2}{*}{ Code } & \multirow{2}{*}{ Mean } & \multicolumn{2}{|c|}{ Normality } & \multirow{2}{*}{$\begin{array}{c}\text { Factor } \\
\text { Loadings }\end{array}$} & \multirow{2}{*}{$\begin{array}{l}\text { Variance } \\
\text { Explained }\end{array}$} & \multirow{2}{*}{$\begin{array}{c}\text { Cronbach's } \\
\text { Alpha }\end{array}$} \\
\hline & & Skewness & Kurtosis & & & \\
\hline Fire Safety Equipment/System 1 & 3.82 & -.273 & -.918 & .643 & 51.89 & 0.907 \\
\hline Fire Safety Equipment/System 2 & 3.81 & -.525 & .248 & .693 & & \\
\hline Fire Safety Equipment/System 3 & 3.68 & -.282 & .570 & .718 & & \\
\hline Fire Safety Equipment/System 4 & 3.64 & -.304 & .515 & .746 & & \\
\hline Fire Safety Equipment/System 5 & 3.48 & -.083 & -.475 & .820 & & \\
\hline Fire Safety Equipment/System 6 & 3.68 & -.439 & -.234 & .807 & & \\
\hline Fire Safety Equipment/System 7 & 3.61 & -.286 & -.047 & .802 & & \\
\hline Fire Safety Equipment/System 8 & 3.81 & -.535 & .846 & .692 & & \\
\hline Fire Safety Equipment/System 9 & 3.61 & .180 & -.689 & .769 & & \\
\hline Fire Safety Equipment/System 10 & 3.70 & -.461 & -.115 & .778 & & \\
\hline Fire Safety Equipment/System 11 & 3.74 & -.217 & -.577 & .746 & & \\
\hline Fire Safety Equipment/System 12 & 3.19 & -.404 & .341 & $* *$ & & \\
\hline
\end{tabular}

$\star \star$ The value is below the recommended threshold

The result obtained is adequate; the data is normally distributed and reliable. Therefore, the instrument is considered valid for the primary research survey except for Fire Safety Equipment/System 12 that requires further amendment.

Table 4 illustrates the pilot result for the Building Components Safety Design constructs which produces mean values between the range of 3.65 and 3.83. The values of skewness and kurtosis were all within the threshold of -/+2 [11], except for Building Components Safety Design 1 which has kurtosis value above 2 . All the variables under the construct have strong factor loadings, with cumulative variance explained, $51.03 \%$, which is considered satisfactory. The reliability of the construct was assessed using the Cronbach's Alpha coefficient which produced a value of 0.917 that is above the recommended minimum threshold of 0.7 [11, 22, 26, 27]. 
Table 4 - Pilot Result for Building Components Safety Design

\begin{tabular}{|c|c|c|c|c|c|c|}
\hline \multirow{2}{*}{ Code } & \multirow{2}{*}{ Mean } & \multicolumn{2}{|c|}{ Normality } & \multirow{2}{*}{$\begin{array}{l}\text { Factor } \\
\text { Loadings }\end{array}$} & \multirow{2}{*}{$\begin{array}{l}\text { Variance } \\
\text { Explained }\end{array}$} & \multirow{2}{*}{$\begin{array}{c}\text { Cronbach's } \\
\text { Alpha }\end{array}$} \\
\hline & & Skewness & Kurtosis & & & \\
\hline Building Components Safety Design 1 & 3.74 & -1.095 & 2.287 & .699 & 51.03 & 0.917 \\
\hline Building Components Safety Design 2 & 3.82 & -.581 & .970 & .738 & & \\
\hline Building Components Safety Design 3 & 3.82 & -.742 & .958 & .781 & & \\
\hline Building Components Safety Design 4 & 3.65 & -.755 & .990 & .722 & & \\
\hline Building Components Safety Design 5 & 3.71 & -.679 & 1.589 & .703 & & \\
\hline Building Components Safety Design 6 & 3.66 & -.131 & -.092 & .708 & & \\
\hline Building Components Safety Design 7 & 3.70 & -.531 & .888 & .719 & & \\
\hline Building Components Safety Design 8 & 3.81 & -.632 & .618 & .621 & & \\
\hline Building Components Safety Design 9 & 3.82 & -.199 & -.028 & .783 & & \\
\hline Building Components Safety Design 10 & 3.82 & -.245 & -.178 & .736 & & \\
\hline Building Components Safety Design 11 & 3.73 & -.188 & -.257 & .722 & & \\
\hline Building Components Safety Design 12 & 3.83 & -.518 & .104 & .769 & & \\
\hline Building Components Safety Design 13 & 3.71 & -.504 & .118 & .552 & & \\
\hline
\end{tabular}

The Cronbach's Alpha value obtained is a sign that the result obtained is adequate, and that the data is normally distributed and reliable. Hence, the instrument is considered valid for the primary research survey of except for Building Components Safety Design 1 which requires further amendment.

Table 5 displays the pilot result for the Users Awareness and Knowledge of Fire Safety construct which produces mean values between 2.81 and 3.69. The values of skewness and kurtosis were all the threshold of $-/+2$ [22]. All the variables under the construct have strong factor loadings which cumulatively explained $58.86 \%$ of the variance and considered satisfactory. The reliability of the construct was assessed using Cronbach's Alpha coefficient which produced a value of 0.948 above the recommended minimum threshold of $0.7[11,22,26,27]$.

Table 5 - Pilot Result for Users Awareness and Knowledge of Fire Safety (UAKFS)

\begin{tabular}{|l|c|c|c|c|c|c|}
\hline \multirow{2}{*}{ Code } & \multirow{2}{*}{ Mean } & \multicolumn{2}{c|}{ Normality } & \multirow{2}{*}{$\begin{array}{c}\text { Factor } \\
\text { Loadings }\end{array}$} & $\begin{array}{c}\text { Variance } \\
\text { Explained }\end{array}$ & $\begin{array}{c}\text { Cronbach's } \\
\text { Alpha }\end{array}$ \\
\cline { 3 - 4 } & & Skewness & Kurtosis & .762 & 58.86 & 0.948 \\
\hline UAKFS 1 & 2.96 & -.068 & -.314 & .752 & & \\
\hline UAKFS 2 & 2.96 & -.370 & -.386 & .752 & & \\
\hline UAKFS 3 & 3.30 & -.294 & .000 & .853 & & \\
\hline UAKFS 4 & 3.21 & -.173 & .350 & .781 & & \\
\hline UAKFS 5 & 3.04 & -.078 & -.277 & .784 & & \\
\hline UAKFS 6 & 3.35 & .163 & -.064 & .758 & & \\
\hline UAKFS 7 & 3.27 & -.041 & .470 & .787 & & \\
\hline UAKFS 8 & 3.26 & .143 & -.300 & .717 & & \\
\hline UAKFS 9 & 3.29 & .029 & -.474 & .734 & & \\
\hline UAKFS 10 & 3.42 & -.122 & -.446 & .781 & & \\
\hline UAKFS 11 & 3.32 & .160 & .930 & .755 & & \\
\hline UAKFS 12 & 3.27 & .092 & .628 & .857 & & \\
\hline UAKFS 13 & 3.36 & .209 & .148 & .706 & & \\
\hline UAKFS 14 & 3.22 & .050 & .338 & .763 & & \\
\hline UAKFS 15 & 3.35 & .106 & -.095 & .691 & & \\
\hline UAKFS 16 & 2.81 & -.102 & -.763 & .474 & & \\
\hline UAKFS 17 & 2.97 & -.100 & -.790 & .512 & & \\
\hline UAKFS 18 & 3.48 & -.497 & .540 & .748 & & \\
\hline UAKFS 19 & 3.48 & -.445 & .297 & .666 & & \\
\hline UAKFS 20 & 3.47 & -.532 & .543 & .616 & & \\
\hline
\end{tabular}




\begin{tabular}{|c|c|c|c|c|c|c|}
\hline \multirow{2}{*}{ Code } & \multirow{2}{*}{ Mean } & \multicolumn{2}{|c|}{ Normality } & \multirow{2}{*}{$\begin{array}{c}\text { Factor } \\
\text { Loadings }\end{array}$} & \multirow{2}{*}{$\begin{array}{l}\text { Variance } \\
\text { Explained }\end{array}$} & \multirow{2}{*}{$\begin{array}{c}\text { Cronbach's } \\
\text { Alpha }\end{array}$} \\
\hline & & Skewness & Kurtosis & & & \\
\hline UAKFS 21 & 3.66 & -.798 & 1.072 & .578 & & \\
\hline UAKFS 22 & 3.60 & -.473 & .562 & .817 & & \\
\hline UAKFS 23 & 3.43 & -.491 & .018 & .752 & & \\
\hline UAKFS 24 & 3.39 & -.637 & .156 & .733 & & \\
\hline UAKFS 25 & 3.69 & -1.072 & 1.570 & .737 & & \\
\hline UAKFS 26 & 3.57 & -.494 & .910 & .825 & & \\
\hline UAKFS 27 & 3.53 & -.337 & .511 & .769 & & \\
\hline UAKFS 28 & 3.58 & -.802 & 1.075 & .581 & & \\
\hline UAKFS 29 & 3.45 & -.417 & .498 & .609 & & \\
\hline UAKFS 30 & 3.53 & -.737 & .596 & .553 & & \\
\hline
\end{tabular}

The obtained result is adequate; the data is normally distributed and reliable. Hence, the instrument is said to be valid for the main survey.

Table 6 portrays the pilot result for the Users Attitude on Fire Safety constructs which produces mean values ranging from 3.48 to 3.79 . The values of skewness and kurtosis were all the threshold of $-/+2$ [19], except for AFS1 and AFS2 which have kurtosis value above 2 . All the variables under the construct have strong factor loadings which cumulatively explained $52.72 \%$ of the variance which is considered satisfactory. The reliability of the construct was assessed using Cronbach's Alpha coefficient which produced a value of 0.885 above the recommended minimum threshold of $0.7[10,11,19,22]$.

Table 6 - Pilot Result for Users Attitude on Fire Safety

\begin{tabular}{|c|c|c|c|c|c|c|}
\hline \multirow{2}{*}{ Code } & \multirow{2}{*}{ Mean } & \multicolumn{2}{|c|}{ Normality } & \multirow{2}{*}{$\begin{array}{c}\text { Factor } \\
\text { Loadings }\end{array}$} & \multirow{2}{*}{$\begin{array}{c}\text { Variance } \\
\text { Explained }\end{array}$} & \multirow{2}{*}{$\begin{array}{c}\text { Cronbach's } \\
\text { Alpha }\end{array}$} \\
\hline & & Skewness & Kurtosis & & & \\
\hline Attitude on Fire Safety 1 & 3.71 & -1.086 & 2.297 & .592 & 52.72 & 0.885 \\
\hline Attitude on Fire Safety 2 & 3.75 & -1.122 & 2.570 & .645 & & \\
\hline Attitude on Fire Safety 3 & 3.61 & -.717 & 1.307 & .659 & & \\
\hline Attitude on Fire Safety 4 & 3.75 & -.962 & 2.356 & .827 & & \\
\hline Attitude on Fire Safety 5 & 3.65 & -.762 & 1.342 & .742 & & \\
\hline Attitude on Fire Safety 6 & 3.48 & -.555 & .118 & .725 & & \\
\hline Attitude on Fire Safety 7 & 3.79 & -1.087 & 1.893 & .780 & & \\
\hline Attitude on Fire Safety 8 & 3.74 & -.895 & 1.367 & .821 & & \\
\hline Attitude on Fire Safety 9 & 3.61 & -.974 & 1.940 & .709 & & \\
\hline
\end{tabular}

This indicates that the result obtained is adequate; the data is normally distributed and reliable. Hence, the instrument is considered valid for the primary survey except for Attitude on Fire Safety 1 and Attitude on Fire Safety 2 which require further amendment.

Table 7 depicts the pilot result for the Effectiveness of Fire Safety Management constructs which produces mean values ranging from 3.55 to 3.83 . The values of skewness and kurtosis were all the threshold of $-/+2$ [11]. All the variables under the construct have strong factor loadings with cumulative variance explained of 62.78 percent which is satisfactory. The reliability of the construct was assessed using Cronbach's Alpha coefficient which produced a value of 0.913 above the rec- ommended minimum threshold of $0.7[11,22$, 26, 27].

This is an indication that the result obtained is adequate; the data is normally distributed and reliable. Hence, the instrument is considered valid for the core survey of the research.

Table 8 presents the descriptive of the constructs used in the users/occupants' questionnaire. The result produced mean values between the range of 3.34 and 3.76 with low dispersion as indicated by standard deviation values of less than 1 . The values of skewness and kurtosis are all within the recommended threshold of $-/+2$ [11]. The results show that all the constructs of the study are normally distributed. 
Table 7 - Pilot Result for Effectiveness of Fire Safety Management

\begin{tabular}{|l|c|c|c|c|c|c|}
\hline \multirow{2}{*}{ Code } & \multirow{2}{*}{ Mean } & \multicolumn{2}{c|}{ Normality } & Factor & $\begin{array}{c}\text { Variance } \\
\text { Explained }\end{array}$ & $\begin{array}{c}\text { Cronbach's } \\
\text { Alpha }\end{array}$ \\
\cline { 5 - 6 } & & Skewness & Kurtosis & Loadings \\
Effectiveness of Fire Safety Management 1 & 3.83 & -.823 & 1.009 & .771 & 62.78 & 0.913 \\
\hline Effectiveness of Fire Safety Management 2 & 3.73 & -.702 & 1.857 & .843 & & \\
\hline Effectiveness of Fire Safety Management 3 & 3.70 & -.531 & .888 & .811 & & \\
\hline Effectiveness of Fire Safety Management 4 & 3.55 & -.699 & 1.196 & .799 & & \\
\hline Effectiveness of Fire Safety Management 5 & 3.65 & -.343 & .834 & .837 & & \\
\hline Effectiveness of Fire Safety Management 6 & 3.73 & -.253 & .941 & .791 & & \\
\hline Effectiveness of Fire Safety Management 7 & 3.75 & -.420 & 1.440 & .625 & & \\
\hline Effectiveness of Fire Safety Management 8 & 3.70 & -.704 & 1.055 & .839 & & \\
\hline
\end{tabular}

Table 8 - Aggregate Descriptive Statistics of Users/Occupants Questionnaire

\begin{tabular}{|l|c|c|c|c|c|c|}
\hline & Mean & Std. Deviation & \multicolumn{2}{|c|}{ Skewness } & \multicolumn{2}{c|}{ Kurtosis } \\
\cline { 2 - 7 } & Statistic & Statistic & Statistic & Std Error & Statistic & Std Error \\
\hline Management & 3.53 & .600 & -.729 & .274 & 1.686 & .541 \\
\hline FS Equipment & 3.65 & .610 & .049 & .274 & -.233 & .541 \\
\hline BLDS Design & 3.76 & .578 & -.465 & .274 & 1.297 & .541 \\
\hline Awareness FS & 3.34 & .611 & -.682 & .274 & 2.267 & .541 \\
\hline FS Attitude & 3.68 & .633 & -1.171 & .274 & 3.935 & .541 \\
\hline FS Effectiveness & 3.70 & .655 & -.885 & .274 & 3.172 & .541 \\
\hline
\end{tabular}

\section{RESULTS AND DISCUSSION}

This research intends to report the results of the pilot study carried out regarding the appraisal of fire safety management effectiveness in Malaysian Higher Education Institutions building facilities from the users' perspectives. The introductory section covers a few issues including the purpose of Fire Safety Management and its roles in the prevention and control of fire. It also highlighted factors that influenced fire safety which encompasses awareness, training and fire protection facilities amongst others [28]. Few challenges that may impede Effective Fire Safety Management were also outlined including the passive attitude of management, housekeeping, and maintenance [2]. Some ways to improve fire safety in buildings such as compartmentation, use of fire-resisting materials, as well as the use of detection and suppression equipment were proposed.

Some essential tests were conducted the using version 23 of SPSS software. The tests carried out based on Pallant's [22] recommendation include the descriptive statistics required for data screening and cleaning to eliminate missing data; the reliability test of the latent constructs which measures the instrument's internal consistency. The test also includes the normality tests of the constructs which measure the respondents' pattern of responses to the questions and the factorability which is a multivariate statistical technique used for analysing the research data to provide information concerning the range of factors that best represent the data [3].

Cronbach's Alpha statistical analysis is an index of reliability that tests the items of measurement or survey variables as well as the internal consistency of the items $[22,27]$. It is usually expressed as a number between 0 and 1 . The value 0 represents no consistency in measurement while 1 portrays a perfect consistency in measurement. Within the range of 1 and 0 , the internal consistency of data can be defined as follows:

Values of $\alpha \geq 0.9$ are considered excellent

$0.9>\alpha \geq 0.8=$ Good

$0.8>\alpha \geq 0.7=$ Acceptable

$0.7>\alpha \geq 0.6=$ Questionable

$0.6>\alpha \geq 0.5=$ Poor and values between

$0.5>\alpha$ are not Unacceptable

The generally accepted value for any Cronbach's Alpha $(\alpha)$ consistency test result is from 0.7 [8, 22]. The result of the pilot analysis from Tables 2 to 7 indicate the values of Cronbach's Alph $(\alpha)$ greater than .9 which illustrated the excellent level of reliability. 


\section{CONCLUSION}

This paper discusses the aim of Fire Safety Management, factors that influence fire safety, challenges that may be encountered in ensuring effective Fire Safety Management for an organisation and a few possible means of improvement. A framework for Effectiveness of Fire Safety Management had been proposed, and this pilot analysis is being undertaken before proceeding with administration of data collection instrument. The pilot testing of administered question- naires was carried out among the users/occupants of Malaysian Higher Education Institutions buildings. A total of 100 questionnaires were distributed, 81 returned among which 77 were useful. A total of 6 constructs were assessed for normality, reliability, factorability. All the results gave a favourable indication for continuing with the central survey with minimal adjustments.

\section{REFERENCES}

1. Abdul Rahim, N., Taib, M., \& Othuman Mydin, M. A. (2014). Investigation of Fire Safety Awareness and Management in Mall. MATEC Web of Conferences, 10, 06004. doi: $10.1051 /$ matecconf/20141006004

2. Agyekum, K., Ayarkwa, J., \& Amoah, P. (2016). Challenges to Fire Safety Management in Multi-Storey Students' Hostels. Modern Management Science \& Engineering, 4(1), 53-61

3. Awang, A. (2014). A handbook on Structural Equation Modelling. Selangor: MPWS.

4. Billington, M. J., Copping, A., \& Ferguson, A. (2008). Means of escape from fire. New York: John Wiley \& Sons.

5. British Safety Council. (2017, August). Fire Safety Management Audit. Retrieved from https://www.britsafe.org/media/3754/ma178-fire-safety-audit-spec-v3.pdf

6. Chow, W. K. (2001). Review on fire safety management and application to Hong Kong. International Journal on Engineering Performance-Based Fire Codes, 3(1), 52-58.

7. Cohen, L., Manion, L., \& Morrison, K. (2013). Research methods in education. London: Routledge.

8. Dunn, T. J., Baguley, T., \& Brunsden, V. (2013). From alpha to omega: A practical solution to the pervasive problem of internal consistency estimation. British Journal of Psychology, 105(3), 399412. doi: 10.1111/bjop.12046

9. Ebenehi, I.Y., Mohamed, S., Sarpin, N. (2018). Fire Safety Management for Buildings in Malaysian Universities: A Conceptual Framework. International Journal of Environmental \& Design and Construction Management, 4, 3-7.

10. Fink, A. (2017). How to conduct surveys: A step-by-step guide (6th ed.). Los Angeles: SAGE.

11. George, D., \& Mallery, P. (2008). SPSS for Windows step by step. A simple study guide and reference. Boston: Pearson.

12. Gollner, M., Kimball, A., \& Vecchiarelli, T. (2012, November). Fire safety design and sustainable buildings: challenges and opportunities. Retrieved from http://www.gollnerfire.com/wpcontent/uploads/2013/05/Foundation_Sustainable_Building_Design_Symposium_ProceedingsFinal.pdf

13. Hassanain, M. A. (2009). Approaches to qualitative fire safety risk assessment in hotel facilities. Structural Survey, 27(4), 287-300. doi: 10.1108/02630800910985081

14. Hassanain, M. A., Hafeez, M. A., \& Sanni-Anibire, M. O. (2017). A ranking system for fire safety performance of student housing facilities. Safety Science, 92, 116-127. doi:

10.1016/j.ssci.2016.10.002 
15. Howarth, D. J., \& Kara-Zaitri, C. (1999). Fire safety management at passenger terminals. Disaster Prevention and Management: An International Journal, 8(5), 362-369. doi: 10.1108/09653569910298288

16. Hung, Y. C. (2012, September). A Study on the Fire Safety Management of Public Rental Housing in Hong Kong. Retrieved from http://lbms03.cityu.edu.hk/theses/c_ftt/engd-ca-b41999095f.pdf

17. International Code Council. (2018). 2018 International building code. Retrieved from http://shop.iccsafe.org/codes/2018-international-codes-and-references/2018-internationalbuilding-code-and-references.html

18. Kironji, M. (2015). Evaluation of Fire Protection Systems in Commercial Highrise Buildings for Fire Safety Optimization: A Case of Nairobi Central Business District. International Journal of Scientific and Research Publications, 5(10), 1-8.

19. Mathers, N., Fox, N., Hunn, A., \& Group, T. (1998). Surveys and Questionnaires. Sheffield: NHS Executive, Trent.

20. Muijs, D. (2010). Doing qualitative research in education with SPSS. London : SAGE Publications.

21. Naziris, I. A., Lagaros, N. D., \& Papaioannou, K. (2016). Selection and Resource Allocation Model for Upgrading Fire Safety of Historic Buildings. Journal of Management in Engineering, 32(4), 05016004. doi: 10.1061/(asce)me.1943-5479.0000424

22. Pallant, J. (2013). SPSS Survival Manual. Maidenhead : Open University Press.

23. Ramachandran, G. (1999). Fire safety management and risk assessment. Facilities, 17(9/10), 363377. doi: $10.1108 / 02632779910278782$

24. Sanni-Anibire, M. O., \& Hassanain, M. A. (2015). An integrated fire safety assessment of a student housing facility. Structural Survey, 33(4/5), 354-371. doi: 10.1108/ss-03-2015-0017

25. Society of Fire Protection Engineers. (2006). SFPE Engineering Guide to Application of Risk Assessment. Gaithersburg: SFPE.

26. Tabachnick, B. G., \& Fidell, L. S. (2014). Using multivariate statistics (6th ed.). Harlow: Pearson.

27. Tavakol, M., \& Dennick, R. (2011). Making sense of Cronbach's alpha. International journal of medical education, 2, 53-55. doi: 10.5116/ijme.4dfb.8dfd

28. Zhang, Y., Zhang, M., \& Qian, C. (2018). System dynamics analysis for petrochemical enterprise fire safety system. Procedia Engineering, 211, 1034-1042. doi: 10.1016/j.proeng.2017.12.107 